\title{
Centimeter scale vertical heterogeneity in bacteria and chlorophyll a
}

\author{
James G. Mitchell*, Jed A. Fuhrman** \\ Marine Sciences Research Center, State University of New York, Stony Brook, New York 11794-5000, USA
}

\begin{abstract}
The vertical distribution of bacterial abundance and chlorophyll a was examined at the centimeter scale with a high resolution sampler and the variation at this scale compared to the variation across the entire water column. Samples were taken near the mouth of Chesapeake Bay, USA, in the coastal Atlantic environment as part of the MECCAS (Microbial Exchanges and Couplings in Coastal Atlantic Systems) program. Bacterial abundance changed up to 5.1 times over the entire water column, while changing up to 3.5 times over $10 \mathrm{~cm}$. Chlorophyll a concentration changed up to 8 times over the entire water column and 5.1 times across the sampler. The high resolution of the sampler revealed steep gradients of bacterial abundance and chlorophyll a. Bacterial abundance changed up to 35 times $\mathrm{m}^{-1}$, while the water column change was up to 2.1 times $\mathrm{m}^{-1}$. Chlorophyll a changed up to 45 times $\mathrm{m}^{-1}$, while the water column changes were less than 2 times $\mathrm{m}^{-1}$ These changes and gradients over small scales indicate that at least under some conditions there are 'small'-scale processes occurring that may be important to plankton ecology, as has been suggested by some theoretical studies.
\end{abstract}

\section{INTRODUCTION}

The Challenger Expedition sampled ocean waters from around the world, seeking the organisms inhabiting the global sea (Hardy 1970). This, along with other early expeditions and investigations, spawned descriptive biological oceanography. Since that time sampling resolution has continued to increase and there has been increasing emphasis on the interactions among organisms and between individual organisms and the environment. Uncoupled, loosely coupled, and tightly coupled are frequently used terms indicative of this increased attention to interactions (Ducklow \& Kirchman 1983). Most organisms at the bottom of marine food webs are microscopic, and as the question of coupling becomes more thoroughly studied, a subdiscipline is emerging that studies how individual microplankton interact (Azam \& Ammerman 1984, Mitchell et al. 1985, Jackson 1987).

At small scales, as with larger scales, one of the first parameters to study is the distribution of organisms.

- Present address: Department of Genetics and Microbiology, Autonomous University of Barcelona, 08193 Bellaterra, Spain

- Present address: Allan Hancock Foundation, University of Southern California, University Park, Los Angeles, California 90089-0371, USA
Hutchinson (1961) implied homogeneity at small scales when he posed the question, The problem that is presented by the phytoplankton is essentially how it is possible for a number of species to coexist in a relatively isotropic or unstructured environment all competing for the same sorts of materials.' Others have inferred heterogeneity at small scales from indirect evidence; Bell \& Mitchell (1972) used the chemotaxis of a few specially chosen bacterial isolates and the documented occurrence of phytoplankton excretion as evidence for the existence of 'phycospheres', clusters of bacteria around excreting phytoplankton. Azam \& Hodson (1981) and Azam \& Ammerman (1984) extended the concept of clustering of bacteria to any nutrient source and found indirect evidence for this extension in the uptake kinetics of natural populations of marine bacteria.

In this paper centimeter scale distributions are measured and discussed. Although centimeters are not of the same scale as the organisms themselves, this is the scale of distance and volume which has been shown to be the best, and in some cases, the necessary, scale to observe distinct motility responses of a small population to a stimulus (Adler 1966, 1969, 1973, Kessler 1985). Additionally, volumes below $25 \mathrm{ml}$ are the scale at which any behavior of individuals is predicted to first be easily observable in marine environments (Mitchell et al. 
1985). Here centimeter scale distributions of microplankton are described and inferences made from these distributions about the interactions of microplankton.

\section{METHODS}

The sampling device consisted of spring-loaded syringes spaced vertically 3 to $5 \mathrm{~cm}$ apart, depending on position along the sampler. Two samples were taken at each depth and the entire sampling interval was $90 \mathrm{~cm}$. Syringes were mounted in a solid aluminium bar $1.5 \mathrm{~m} \times 15 \mathrm{~cm} \times 2.5 \mathrm{~cm}$. A lever attached by a hinge at one end was used to depress and release all syringes simultaneously (Fig. 1). A trip wire released the bar, the springs moved the plungers three-quarters of the way out of the barrel and the syringes filled in less than $2 \mathrm{~s}$ (Mitchell 1988). Four quick-response (time constant.
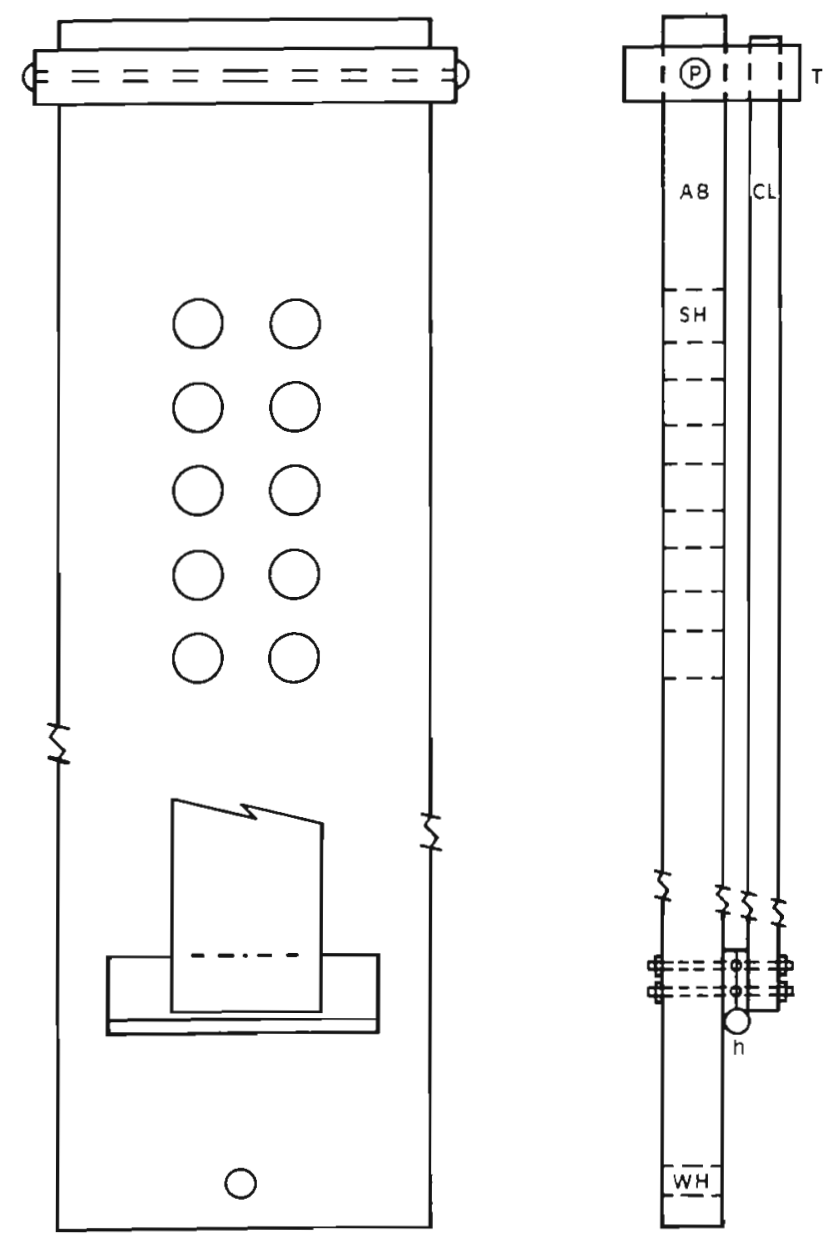

Fig. 1 The sampler used in this study. Left: front view; right: sideview. Center to center distance between syringe holes is $4 \mathrm{~cm}$ horizontally and $3.3 \mathrm{~cm}$ vertically. $A B$ : aluminium bar. $\mathrm{CL}$ : compression lever; $\mathrm{T}$ : trigger; $\mathrm{P}$ : trigger pivot; $\mathrm{SH}$ : syringe hole $;$ h: hinge; WH: weight hole. Photographs of various parts of the sampler can be found in Mitchell (1988)
$18 \mathrm{~ms})$ thermistors were placed at $30 \mathrm{~cm}$ intervals along the sampling devices, and extended out beyond the tips of the syringes by about $1 \mathrm{~cm}$. The thermistors were used for positioning the sampler in the thermocline. Temperatures along the length of the sampler were read in real time with an on-deck readout, and values observed on the screen could be printed out when desired (e.g. upon filling the syringes). Depth was measured from the top of the sampler by the length of wire below the sea surface. The sampler was used only during relatively calm periods to minimize vertical averaging and wire angle.

Samples were taken in the Atlantic just outside the mouth of the Chesapeake Bay $\left(3700^{\circ} \mathrm{N}, 7615^{\circ} \mathrm{W}\right)$ as part of the MECCAS (Microbial Exchanges and Coupling in Coastal Atlantic Systems) program during June and August 1985. The sampler was positioned in the pycnocline by the thermistor chain and CTD measurements. A vertical profile was generated from the CTD and used to initially find the pycnocline, while the thermistors attached to the sampler were used for exact placement.

Bacteria were counted using the acridine orange method of Hobbie et al. (1977). All counts were done on an Olympus epifluorescence microscope with blue $(400$ $\mathrm{nm})$ filters for excitation and green $(525 \mathrm{~nm})$ for emission.

For measuring chlorophyll a, $10 \mathrm{ml}$ of sample were filtered onto $0.45 \mu \mathrm{m}$ HA Millipore filters. The filters were quickly wrapped in aluminium foil and placed in a dark freezer for later measurement. The remaining sample was fixed with gluteraldehyde, final concentration $2.5 \%$. Chlorophyll a was extracted in $10 \mathrm{ml}$ of $90 \%$ acetone (Phinney \& Yentsch 1985), vortexed, kept in a dark freezer for $24 \mathrm{~h}$, centrifuged, and a subsample gently poured into a cuvette. Readings were taken on a Turner Designs fluorometer, 2 drops of $10 \% \mathrm{HCl}$ added and the cuvette read (Parsons et al. 1984)

Bacterial growth rates were measured twice on the August MECCAS cruise using the thymidine incorporation method (Fuhrman \& Azam 1982). Five to $10 \mathrm{ml}$ of sample were dispensed into clean $20 \mathrm{ml}$ scintillation vials. When all vials contained sample the tritiated thymidine was added with an autopipet, final concentration $5 \mathrm{nM}$. This took 2 to $3 \mathrm{~min}$. After samples had been incubated at in situ temperatures for $1 \mathrm{~h}$, incorporation was stopped by placing the samples on ice in a deep freezer and adding 10\% TCA, followed by filtering on HA Millipore filters $(0.45 \mu \mathrm{m}$ pore size). The filters were rinsed 7 times with distilled water and stored in scintillation vials for later counting.

A total of 200 to 1000 bacteria were counted among 10 microscope fields for each sample. The mean and standard deviation of the sample were calculated from the counts. All tests for significant differences between the 
means for counting were evaluated at the 0.01 level using Tukey's comparison of means test (Sokal \& Rohlf 1981). For eukaryotic autotrophs, counts were done by scanning transects of known length across the filter. The length of the transect was measured with the stage vernier micrometer. The objective of 200 cells counted per filter could not always be reached and of ten a transect was ended after 100 cells had been counted. Counts of eukaryotes were performed at a magnification of 1250 times to ensure correct identification as photosynthetic eukaryotes. For in vivo fluorescence and chlorophyll a measurements, only one number was obtained from each syringe sample due to the volume required for each sample. The 4 MECCAS vertical profiles are representative of a catalogue of 71 profiles (Mitchell 1988).

\section{RESULTS}

\section{Bacterial abundance}

Bacterial abundance in the June MECCAS profiles changed by up to a factor of 2 over a $10 \mathrm{~cm}$ vertical distance (Fig. 2). In this profile the increase in abun-
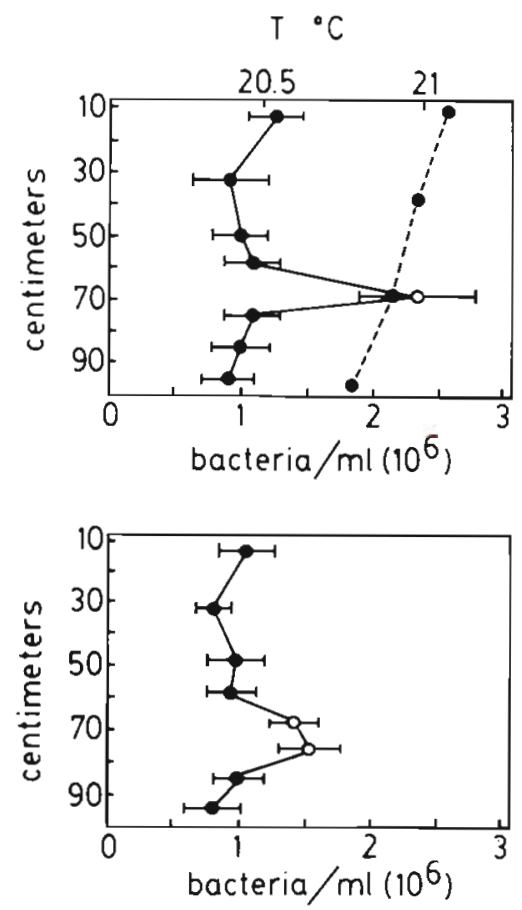

Fig. 2. Bacterial abundance $\left(10^{6}\right.$ cells $\left.\mathrm{ml}^{-1}\right)$ measured on the 27 June 1985 MECCAS cruise. Top: Left set of syringes. Bottom: Right set of syringes. The distance on the $y$-axis is measured from the top of the sampler, which was at $4 \mathrm{~m}$ depth. Error bars are \pm 1 standard deviation of the mean for 1 sample per syringe. Solid circles are not statistically different from each other at the 0.01 level, but are different from the open circles at the 0.01 level by a Tukey's comparison of means test, using the sample variance dance near $70 \mathrm{~cm}$ occurred in both the left and right sets of syringes, and the peak in abundance at the right set of syringes appeared truncated, indicating the sampler may have sampled the shoulders of a peak.

In addition to 1 and 2 point peaks in abundance (Fig. 2 ), there was also a trend across the profile in the case of Fig. 3. In both the left and right sets of syringes abundance decreased with depth, with the shallowest samples being significantly greater than the deepest samples $(p<0.01)$. Abundances at 60 and $70 \mathrm{~cm}$ in the left profile were different from each other by $23 \%$ $(p<0.01)$. The abundances at the same positions on the right profile differed by only $2.2 \%$ (not significant).
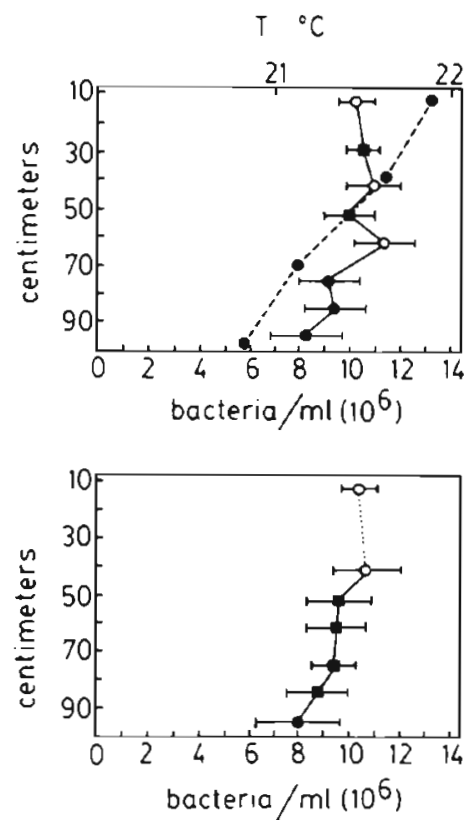

Fig. 3. Bacterial abundance $\left(10^{6}\right.$ cells $\left.\mathrm{ml}^{-1}\right)$ measured on the 24 June 1985 MECCAS cruise. Top: Left set of syringes. Bottom: Right set of syringes. The distance on the $y$-axis is measured from the top of the sampler, which was at $5 \mathrm{~m}$ depth. Error bars are \pm 1 standard deviation of the mean. Solid circles are not statistically different from each other at the 0.01 level, but are different from the open circles at the 0.01 level by a Tukey's comparison of means test, using the sample variance. Squares do not differ from hollow or solid circles

Salinity and temperature showed that the water sampled for profiles in Fig. 2 was mixed, detectable salinity stratification was absent and temperature decreased less than $0.30^{\circ} \mathrm{C}$ with depth.

The water column from which samples for Fig. 3 were taken had gradients over the sampler depth of $2.5 \mathrm{C}^{\circ}$ and $2.9 \%$. The thermistor profile made at the time the samples were taken showed a total difference of $0.96^{\circ} \mathrm{C}$, with the absolute temperatures ranging from 20.91 to $21.87^{\circ} \mathrm{C}$. A thermistor profile from the same depth 19 min earlier showed a gradient of $1.93^{\circ} \mathrm{C}$ with an absolute temperature range of 17.23 to $19.16^{\circ} \mathrm{C}$. 
The August and September MECCAS abundance profiles show characteristics similar to the June profiles. The most noticeable differences were the decreased absolute abundances in the August to September profiles versus the June profiles, and the prominence of single point maxima. None of these maxima occurred in both members of a left-right syringe pair (Fig. 4).
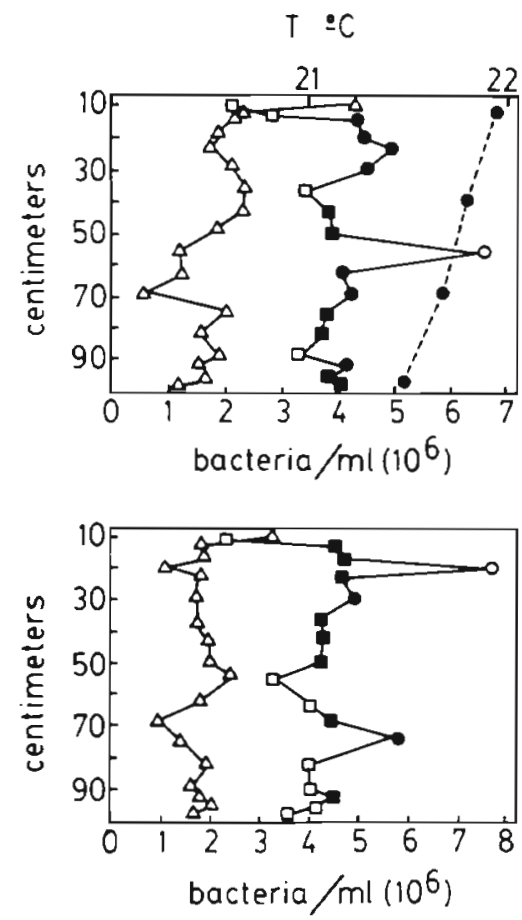

Fig. 4. Data collected on 31 Aug 1985 MECCAS cruise. Top: Left set of syringes. Bottom: Right set of syringes. The distance on the $y$-axis is measured from the top of the sampler, which was at $9 \mathrm{~m}$ depth. Squares and circles are bacterial abundance $\left(10^{6}\right.$ cells $\left.\mathrm{ml}^{-1}\right)$. Triangles are relative thymidine incorporation. rate. Hollow squares are significantly different from all circles at the 0.01 level. Solid squares are not significantly different from either the hollow squares below or the solid circles above them. Solid circles are significantly different from the hollow squares and the hollow circles at the 0.01 level. Hollow circles are different from all lower values at the 0.01 level

Variability in bacterial abundance was compared between sampler profiles and profiles of the entire water column taken with 51 Niskin bottles. The water column profiles were from other MECCAS stations close to the sampler station. Profiles consisted of bacterial abundance data from 2 to 4 depths. The absolute abundance for all stations ranged from $0.7 \times 10^{6}$ to $5.5 \times 10^{6}$ cells $\mathrm{ml}^{-1}$. To facilitate comparison between profiles the largest value in a profile was divided by the smallest number in the profile. The resulting number is the factor by which the abundance changes over the profile. For example, the largest change for the whole water column profiles was a change of 5.1 times $\left(7.6 \times 10^{6} / 1.5 \times\right.$ $10^{6} \mathrm{ml}^{-1}$ ). With each pair of sampler profiles in the figures there were associated whole water column (wc) profiles. The relation of change in bacterial abundance between the wc profiles and sampler profiles varied. For Fig. 2 the bacterial abundance of the associated wC profiles changed from 3.2 to 5.1 times. The change across the sampler profile was 2.6 times. For Fig. 3 the change across the wc profiles was 1.0 (no change) to 2.5 times and the sampler profile changed by 1.4 times. For Fig. 4 the wc profiles changed 1.2 to 2.6 times in comparison to 3.5 times across the sampler profile

In addition to the magnitude of the change, the steepness of the change (the gradient) is important for some biological processes (see 'Peak duration' in the 'Discussion'). The gradients were standardized to change per meter for purposes of comparison. For the sampler profiles of Figs. 2, 3 and 4 the maximal changes per meter were $7.4,4.0$, and 35.0 times. The corresponding whole water profiles had gradients of 1.32 to 2.10 times $\mathrm{m}^{-1}, 1.08$ to 1.38 times $\mathrm{m}^{-1}$ and 1.21 to 2.00 times $m^{-1}$.

\section{Chlorophyll a}

Precision of the chlorophyll a method was found to be $7 \%(95 \% \mathrm{CI})$ by repeated measurements from a $50 \mathrm{ml}$ sample. This measurement is within the $8 \%$ precision that Strickland \& Parsons (1968) state the fluorometric method should yield. The chlorophyll a profiles (Fig. 5) showed pronounced peaks and troughs. Profiles from the left and right sets of syringes both show 3 major peaks, although the peaks of the right profile are smaller and displaced toward the deeper end of the profile. In contrast to the pairs being out of phase with each other at the deeper points, the pairs at the shallowest 4 points are in phase and follow each other closely. The profiles do not diverge significantly until the seventh pair of points at $36.3 \mathrm{~cm}$.

The chlorophyll a variability shown in Fig. 5 was compared to the variability in the 25 nearest whole water column profiles in time and space. The absolute range of chlorophyll a values for all water column samples of

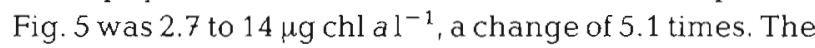
steepest gradient in the profile is a change of 3 times over $6.6 \mathrm{~cm}$, a change of about 45 times $\mathrm{m}^{-1}$. The range of chlorophyll a over all water column profiles was 0.2 to $7.6 \mu \mathrm{g} \mathrm{chl} \mathrm{al} \mathrm{l}^{-1}$. There were 2 to 8 samples for each water column profile. There was no change over the length of some water column profiles, while other profiles changed by up to 8 times. Water column profile changes were less than 2 times $\mathrm{m}^{-1}$.

Salinity and temperature profiles corresponding to Fig. 5 showed that the water was stratified. The CTD temperature and salinity gradients were $1.70 \mathrm{C}^{\circ}$ and $2.0 \% \mathrm{~m}^{-1}$. The thermistor gradient was $0.93 \mathrm{C}^{\circ}$. At this 

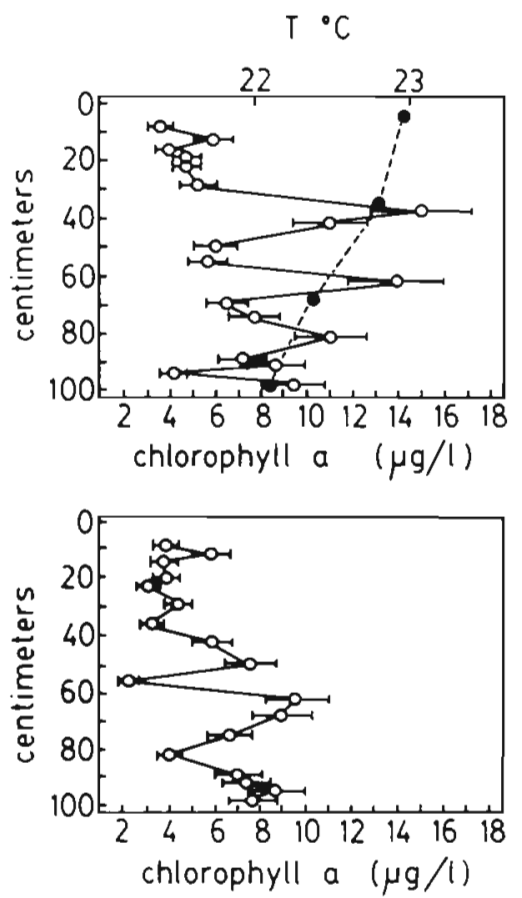

Fig. 5. Chlorophyll a concentrations $\left(\mu \mathrm{g} \mathrm{l}^{-1}\right)$ on the $28 \mathrm{Aug}$ 1985 MECCAS cruise. Top: Left set of syringes. Bottom: Right set of syringes. The distance on the $y$-axis is measured from the top of the sampler, which was at $9.5 \mathrm{~m}$ depth. There was insufficient sample for replicates. The error bars are $\pm 13 \%$, or twice the measured error of the method

station only the temperature from the lowest $10 \mathrm{~cm}$ of the CTD profile overlaps with the thermistor profile, suggesting the sampler may have been almost a meter below the bottom of the CTD profile. For the few minutes before the samples were taken the thermistor fluctuated between the $0.93 \mathrm{C}^{\circ} \mathrm{m}^{-1}$ gradient recorded and a gradient of as much as $2 \mathrm{C}^{\circ} \mathrm{m}^{-1}$. Bottom depth was $9.5 \mathrm{~m}$.

\section{Thymidine incorporation}

The thymidine incorporation rates in the upper half of the profiles showed a general trend, a growth rate inversely proportional to cell abundance (Fig. 4). A departure from this occurred at 40 to $80 \mathrm{~cm}$ in one profile (Fig. 4a).

Salinity and temperature for Fig. 4 show the water was mixed. The CTD temperature and salinity gradients were $0.03 \mathrm{C}^{\circ}$ and $0.003 \% \mathrm{~m}^{-1}$. The thermistor gradient was $0.45 \mathrm{C}^{\circ}$. Bottom depth was $13 \mathrm{~m}$.

\section{DISCUSSION}

The results establish that microplankton distributions are heterogeneous down to lengths of $3.3 \mathrm{~cm}$ vertically and $4.0 \mathrm{~cm}$ horizontally in ocean water. The mechan- isms behind this heterogeneity are not yet clear, but some possibilities are discussed below. These mechanisms include the presence of chemical micropatches and loosely aggregated organic particles (Alldredge \& Cohen 1987), swarming by motile cells, population growth at interfaces and intrusions of one water mass into another.

\section{Single point abundance peaks}

To eliminate the chances of the single point abundance peaks being artifacts due to a lack of preservation, all samples with peaks were tested (a saturated $\mathrm{KMnO}_{4}$ solution turns brown in the presence of aldehyde) to make sure they had been fixed. These samples all tested positive for the presence of aldehyde fixative. These peaks are also unlikely to be due to statistical variation associated with samples that contain a small number of cells, since as described above samples contained millions of cells $\mathrm{ml}^{-1}$ and between 200 and 1000 cells were counted for each sample.

Fig. 3 contains single point peaks of bacterial abundance. Syringes and sample vials were cleaned or sterile before use and samples containing peaks tested positive for aldehyde preservatives, so contamination and continued growth seems unlikely. The peaks might be explained by the presence of a thin discrete layer of increased cell number, but they were not found in both members of syringes at the same depth.

Possibly, the peaks represented volumes of water that contained loose organic aggregates (marine snow) which were dispersed during passage into and out of the syringes. The intake is particularly disruptive to large particles. The syringes fill with about $15 \mathrm{ml}$ of water through a hole with a $1 \mathrm{~mm}$ radius in about $1 \mathrm{~s}$. The shear from the wall to the center of the tube exceeds 5000 ( $\left.\mathrm{cm} \mathrm{s}^{-1}\right) \mathrm{cm}^{-1}$. At this shear small bubbles from cavitation would further contribute to the destruction of any loosely aggregated particles (marine snow). For comparison, the maximum turbulent shear in the ocean is about $1\left(\mathrm{~cm} \mathrm{~s}^{-1}\right) \mathrm{cm}^{-1}$. If a marine snow particle with few bacteria $\left(2 \times 10^{6}\right.$, Alldredge et al. 1986) is dispersed throughout a $15 \mathrm{ml}$ sample, the concentration of bacteria in the $15 \mathrm{ml}$ increases by about $1 \times 10^{5}$ cells $\mathrm{ml}^{-1}$, or less than $10 \%$ of the free observed cell concentration. If, however, a particle with many bacteria $\left(2 \times 10^{8}\right.$ bacteria, Alldredge et al. 1986) is dispersed the concentration increases by about $1 \times 10^{7}$ cells $\mathrm{ml}^{-1}$. This is sufficient to explain the largest peaks observed, but does not prove that a dispersed particle caused the peaks.

Comparing the number of large single point peaks to the total volume of all syringes sampled (about $8 \mathrm{l}$ ) gives a marine snow particle concentration of 0.75 particles $l^{-1}$ (Mitchell 1988). This compares well with the value of 
1 per liter (Alldredge et al. 1986) for a similar Atlantic environment, considering: (1) the crudeness of the calculation here, (2) that not all marine snow particles have enough bacteria to noticeably raise the concentration, and (3) that the study by Alldredge et al. (1986) had a sample number for this environment of 2 .

\section{Comparing physical and biological profiles}

Some sets of samples (represented by Figs. 2 and 4) were taken from mixed and some other sets of samples (represented by Figs. 3 and 5) were taken from stratified water. All samples contained peaks and troughs in cell abundance, bacterial growth rate or chlorophyll a concentration. This might lead to the conclusion that stratification had no influence on the distribution of microplankton. However, closer examination of the figures does suggest a possible difference between the distributions of microplankton in stratified versus mixed or slightly stratified water.

The prominent feature of profiles from stratified water was the trend across the entire profile. Fig. 3 is an example of a trend in the distribution of bacterial abundance, with the highest abundances at the shallowest depths. For Fig. 5 there appeared to be trends down the profile, but there were also peaks and troughs extending from the baseline. For Fig. 5 this more complicated pattern might have resulted from the bottom having been less than a meter away.

The prominent features of profiles from mixed water were the peaks and troughs that extended out from and returned to a constant baseline level. Fig. 2 is a clear example that shows no statistically significant trend in bacterial abundance across the length of the sampler. Instead, the dominant feature of Fig. 2 is the peak at 70 to $80 \mathrm{~cm}$.

We believe that 2 different mechanisms are responsible for the 2 different kinds of profiles. A trend across a large part or all of an entire profile may indicate an interface between 2 water masses, and could result from migration of organisms in water where turbulence is weak enough to be easily overcome by motility, as described below ('Peak duration'). For mixed and slightly stratified water, the peaks and troughs could be patches of cells concentrated or dispersed by the random fluctuations of turbulently generated shear (Mitchell et al. unpubl.).

\section{Comparing sampler and water column profiles}

The water column profiles of bacterial abundance ranged from no change to changing by a factor of 5.1 times and the sampler profiles had a range of 1.4 to 3.5 times. The absolute abundances were also similar in both types of profiles. The absolute abundance in Fig. 3 was higher than any of the surrounding water column profiles and might have been a result of the sampler profile being a meter closer to the bottom than any of the water column profile Niskin bottles.

The changes in bacterial abundance per meter of depth for the sampler were generally greater, 4 to 35 times $\mathrm{m}^{-1}$, than the water column changes, 1 to 4.9 times $\mathrm{m}^{-1}$. If this were a function of sampling resolution then the steepness of gradients would simply be a function of sampling scale. The profiles indicate this is not necessarily the case (Figs. 2 to 5; Mitchell 1988). The importance of calculating gradients is that the steeper a gradient the greater the effort required to generate and maintain it against diffusion. The kinds of diffusive processes involved and the significance of steep gradients is explained below ('Peak duration').

The absolute abundance of the chlorophyll profile of Fig. 5,2.7 to $14 \mu \mathrm{g} \mathrm{chl} \mathrm{al}^{-1}$, was somewhat higher than the range for the surrounding water columnn profiles, 0.2 to $7.6 \mu \mathrm{g} \mathrm{chl} \mathrm{al} \mathrm{l}^{-1}$. This may have been because the sampler was used at a meter deeper and a time and position intermediate among the water column profiles. For gradient steepness the whole water column profiles were 1 to 8 times $\mathrm{m}^{-1}$, and for the sampler profile 45 times $\mathrm{m}^{-1}$. As with the steeper gradients in bacterial abundance, steep chlorophyll gradients diffuse away quickly unless energy is expended to maintain them. The formation and destruction of these can be driven by biological or physical processes as discussed below ('Peak duration').

\section{Growth rate versus abundance}

Fig. 4 compares cell abundance to incorporation of tritiated thymidine per cell. In both profiles the per cell incorporation rate was highest where cell number was lowest. High growth rate and low number would seem to imply the bacterial growth rate is high at this depth and that the population is being removed. Removal could be due to emigration by motility. However, at a taxis velocity of even $10 \mu \mathrm{m} \mathrm{s}^{-1}$ thousands of seconds are required to generate the observed distribution. Removal could also be due to grazing, if the grazers at this depth were more numerous or more actively feeding than at surrounding depths. Grazing might also explain the higher activity levels if the grazers are regenerating nutrients as is believed (Ducklow \& Kirchman 1983).

\section{Peak duration}

How long do peaks and troughs in cell abundance persist before they are reduced by mixing or cell motil- 
ity? Since the profiles are single time point samplings the data do not measure the lifetimes of the peaks and troughs. The lifetime can be estimated, however, from the peak to background (or trough) distance, swimming speed of individual bacteria, and the turbulent eddy diffusivity. The peak lifetime is considered the time required to go from the original elevated cell number to $1 /$ e of that number.

The lifetime of a bacterial peak can be estimated using lifetime $=h^{2} / 2 D$, where $h$ is the peak to background distance along the baseline, and $\mathrm{D}$ is the diffusivity due to bacterial swimming or turbulent eddies (Berg 1983). An average bacterial swimming speed is $30 \mu \mathrm{m} \mathrm{s}^{-1}$ (Berg 1975) and eddy diffusivity is $0.01 \mathrm{~cm}^{2}$ $\mathrm{s}^{-1}$ in well-stratified water and $0.1 \mathrm{~cm}^{2} \mathrm{~s}^{-1}$ in more thoroughly mixed water (Okubo 1971, 1980). The time required to disperse a peak due to eddy diffusivity is about $9 \mathrm{~min}$ at $3.3 \mathrm{~cm}$ separation of peak and background along the baseline. Dispersion by swimming is an order of magnitude faster, so that about $1 \mathrm{~min}$ is required if the movement is random and there is no signal to keep the bacteria clustered (Fig. 6).

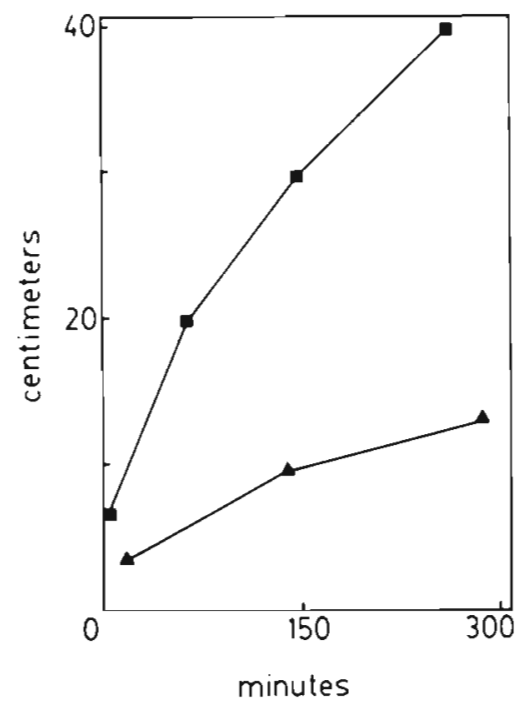

Fig. 6. Graph of times required to disperse a peak versus the peak to trough distances. ( $₫$ ) Eddy diffusivity alone; ( $\bullet$ ) bacterial motility

Conversely, peaks in bacterial abundance may also form in a few minutes. Thus, for motile bacteria in calm water, swimming determines dispersion rates. In more thoroughly mixed water, where the turbulent eddy diffusivity is of the same order or larger than the biologically generated diffusivity, eddy diffusivity and biological diffusivity add together to give dispersion in less than a minute at $3.3 \mathrm{~cm}$ separation. Motile bacteria cannot, however, overcome higher eddy diffusivities to form a peak.

The above are minimal theoretical estimates for peak lifetimes and do not indicate whether bacterial peaks and gradients are transient, dispersing in a few minutes, or whether the bacteria maintain these gradients against diffusion for hours, as would be necessary if the part of the peaks were to result from growth of the population at that depth.

Under at least some circumstances centimeter scale variation in microplankton abundance can equal or exceed variation for the whole water column. The mechanisms that create and maintain this variation are not known for the ocean, although chemotaxis has been proposed as one possibility (Mitchell et al. 1985, Jackson 1987). Physical mechanisms such as bioconvection which are based on cell morphology and density might also cause small-scale variation in abundance. These mechanisms can allow a small cluster of cells to travel up to 10 times faster than a single isolated cell (Kessler 1986). Whatever the mechanism, such small-scale changes in distributions of microplankton may be at least as important to the plankton and their ecology as changes over the whole length of the water column. Indeed, it is at the volumes of milliliters and below that predation, particle encounter and nutrient uptake occur. Further study of distributions and processes at this scale should considerably advance understanding of microplankton ecology.

Acknowledgements. The authors thank A. Okubo, C. PedrósAlió, J. Hobbie, and T. Malone for valuable advice. T. Malone, W Boicourt, J. Hobbie, A. Giblin, E. Carpenter, C. Taylor, C. Lee, and D. Caron generously provided ship time, equipment and laboratory facilities. T. Wilson built the thermistor string G. McManus, W. Peterson, H. Dam, H. Stuebe, S. Leffert, J. McDaniel, J. Montoya, C. Garside, H. Ducklow, S. Hill, C. Moore, C. Barnes, L. Sanford, P. Gilibert, M. Roman, C. Lee, J. Molongowski, J. Helfrich, B. Robinson, and K. Ho gave time and logistical support along with the crews of the RVs 'Gyre', 'Cape Hatteras', and 'Onrust'. J. Manel Cuartero drafted the figures. This research was part of the MECCAS program and was supported directly or indirectly by all MECCAS related grants. Specifically, this work was supported by grants to J. A F., NSF OCE 8214498 and OCE 8207523, and a Jesse SmithNoyes Foundation graduate research fellowship to J. G. M.

\section{LITERATURE CITED}

Adler, J. (1966). Chemotaxis in bacteria: motile Escherichia coli migrate in bands that are influenced by oxygen and organic nutrients. Science 153: 708-716

Adler, J. (1969). Chemoreceptors in bacteria: studies of chemotaxis reveal systems that detect attractants independently of their metabolism. Science 166: 1588-1597

Adler, J. (1973). A method for measuring chemotaxis and use of the method to determine optimum conditions for chemotaxis by Escherichia coli. J. gen. Microbiol. 74: $77-91$

Alldredge, A. L., Cohen, Y. (1987). Can microscale chemical patches persist in the sea? Microelectrode study of marine snow fecal pellets. Science 235: 689-691 
Alldredge, A. L., Cole, J. J., Caron, D. A. (1986). Production of heterotrophic bacteria inhabiting macroscopic organic aggregates (marine snow) from surface waters. Limnol. Oceanogr. 31(1): 68-78

Azam, F., Ammerman, J. W. (1984). Cycling of organic matter by bacterioplankton in pelagic marine ecosystems: microenvironmental considerations. In: Fasham, M. J. R. (ed.) Flows of energy and materials in marine ecosystems. Plenum Publ., p. 345-360

Azam, F., Hodson, R. E. (1981). Multiphasic kinetics for Dglucose uptake by assemblages of natural marine bacteria. Mar. Ecol. Prog. Ser. 6: 213-222

Bell, W., Mitchell, R. (1972). Chemotactic and growth responses of marine bacteria to algal extracellular products. Biol. Bull. mar biol. Lab., Woods Hole 143 (2): 265-277

Berg, H. C. (1975), Bacterial behavior Nature, Lond. 254: 389-392

Berg, H. C. (1983). Random walks in biology. Princeton University Press, Princeton

Ducklow, H. W., Kirchman, D. L. (1983). Bactreial dynamics and distribution during a spring diatom bloom in the Hudson River Plume, U.S.A. J. Plankton Res. 5 (3): 333-335

Fuhrman, J. A., Azam, F. (1982). Thymidine incorporation as a measure of heterotrophic bacterioplankton production in marine surface waters: evaluation and field results. Mar. Biol. 66: 109-120

Hardy, A. (1970). The open sea: its natural history. Houghton Mifflin Co., Boston

Hobbie, J. E., Daley, R. J., Jasper, S. (1977). Use of Nuclepore filters for counting bacteria by fluorescence microscopy. Appl. Environ. Microbiol. 33: 1225-1228

This article was submitted to the editor
Hutchinson, G. E. (1961). The paradox of the plankton. Am. Nat. 95 (882): 137-141

Jackson, G. A. (1987). Simulating chemosensory responses of marine microorganisms. Limnol. Oceanogr. 32: 1253-1266

Kessler, J. O. (1985). Hydrodynamic focusing of motile algal cells. Nature, Lond. 313: 218-220

Kessler, J. O. (1986). The external dynamics of swimming micro-organisms. In: Round, F. E., Chapman, D. J. (eds.) Progress in phycological research Vol. 4. Biopress, Bristol, p. $267-318$

Mitchell, J. G. (1988). Microplankton live in a structured environment. Ph. D. thesis, State University of New York, Stony Brook

Mitchell, J. G., Okubo, A., Fuhrman, J. A. (1985). Microzones surrounding phytoplankton form the basis for a stratified marine microbial ecosystem. Nature, Lond. 316: 58-59

Okubo, A. (1971). Horizontal and vertical mixing in the sea. In: Hood, D. W. (ed.) Impingement of man on the oceans. J Wiley and Sons, New York, p. 89-168

Okubo, A. (1980). Diffusion and ecological problems: mathematical models. Biomathematics series 10. SpringerVerlag, New York

Parsons, T R., Maita, Y., Lalli, C. M. (1984). A manual of chemical and biological methods for seawater analysis. Pergamon, New York

Phinney, D. A., Yentsch, C. S. (1985). A novel phytoplankton chlorophyll technique: toward automated analysis. J Plankton Res. 7: 633-646

Sokal, R. R., Rohlf, J. F. (1981). Biometry. W. H. Freeman Co. New York, p. 859

Strickland, J. D. H., Parsons, T R. (1968). A practical handbook of seawater analysis. Bull. Fish. Res. Bd Can. 167

Manuscript first received: November 28, 1988

Revised version accepted: February 27, 1989 